\title{
Multi-Criteria Evaluation (MCE) Method for the Management of Woodland Plantations in Floodplain Areas
}

\author{
Christos Tzioutzios ${ }^{1}\left[\mathbb{D}\right.$ and Aristeidis Kastridis ${ }^{2, *}$ \\ 1 Department of Geographical Information Systems, University of Aberdeen, Aberdeen AB24 3UE, UK; \\ ctzioutz@gmail.com \\ 2 Department of Mountainous Water Management Control, Faculty of Forestry and Natural Environment, \\ Aristotle University of Thessaloniki, 54124 Thessaloniki, Greece \\ * Correspondence: akastrid@for.auth.gr; Tel.: +30-2310998984
}

Received: 15 October 2020; Accepted: 4 December 2020; Published: 5 December 2020

\begin{abstract}
The potential of woodland and floodplain woodland plantations in a wide area, of high flood risk, along the Spey River (Scotland) is investigated, to mitigate the floods' catastrophic impact. The spatial analysis required various datasets to be overlaid, to define the suitable sites for woodland and floodplain woodland establishment. These datasets that concern the topography, the physical and technical characteristics (existing woodland, road system, urban and rural areas, river system and open water areas, railway) and the protected sites of the study area were obtained and merged using Geographical Information System (GIS) techniques. The most suitable and unsuitable areas within the region were identified, using multi-criteria evaluation methods (Boolean approach). In total, 13 constraints were created by expressing true/false statements for each factor, and were combined together using spatial analysis tools. The results revealed the high potential of woodland and floodplain woodland plantations to prevent floods, with $59.2 \%$ of the total study area $\left(177.5 \mathrm{Km}^{2}\right)$ determined to be appropriate for such practices' application. The River Dulnain tributary demonstrated the highest potential for floodplain woodland planting, followed by Rivers Avon and Fiddich, and the southwestern and northeastern Spey River parts. The methodology proposed is simple and provides rapid and accurate results at low cost, while the datasets can be easily accessed and are available in convenient type/format. This useful methodology for researchers and authorities could be applied successfully to similar watersheds, contributing significantly to flood risk mitigation and the enhancement of the flood-preventative measures' planning efficiency.
\end{abstract}

Keywords: multi-criteria evaluation; flood risk mitigation; riparian woodland; floodplain; woodland planting

\section{Introduction}

Floods are considered to be one of the most devastating natural disasters, causing significant damage both to the environment and human society. They are responsible for more than half of all disaster-related fatalities and one third of the economic loss caused by all the natural catastrophes [1]. Climate change affects the freshwater environment, both the timing and volume of river flows and the extent of groundwater recharge. In particular, there is a growing concern about the increased risk of flooding and soil erosion as wetter winters and more frequent extreme rainfall events occur throughout the year [2].

Flood incidents have become more frequent and severe in Europe over the past years, with an increasing apprehension that human actions may play a key role in this. It is widely recognized that 
both the human activities and the natural processes affect the hydrological dynamics of the rivers and can lead to flood incidents [3-9]. Climate change contributes to the generation of extreme rainfalls and storms, while the current rapid urbanization and land use changes intensify even more the flood risk [10-13]. Europe has experienced a series of major floods the past years-extreme floods in central Europe in 2002 and in England during the summer of 2007, the unprecedented flash floods in western Italy in 2011, the extreme floods in central Europe in June 2013, etc. [14]. In order to reduce and mitigate the catastrophic results of the increased flood incidents rates, a flood prevention strategy that will involve flood management plans and measurements should become a matter of first priority.

Extensive research has been conducted so far, on the addressing of the flood prevention challenge, concerning the appropriate management plans, with some of them to focus on structural approaches such as building dikes, dams, flood control reservoirs and diversions [15]. However, there is a growing support of the "catchment scale" approaches, focusing on a more sustainable way of management, including practices that also involve the rural areas in the management plans [16]. The increased number of flood incidents in recent years reveals that the problem can no longer be solved by building more flood defenses. There is a need to prioritize the flood management in the floodplain, aiming to manage more efficiently the maximum flood discharge, applying more sustainable methods of flood control. One of these practices is woodland and riparian woodland planting along the riverbed, aiming at the reduction of the extreme runoff and the flood control of the floodplain. By utilizing the advanced capabilities that Geographical Information Systems (GIS) could provide, this task can be accelerated, providing results and decisions in a less time-consuming, more efficient and more precise manner.

Riparian forests are considered to be one of the most diverse, dynamic and complex ecosystems in the world, while they are among the most sensitive, human-influenced and -threatened ecosystems as well [17]. The expansion of riparian woodland in flood-vulnerable areas could contribute both to flood control and other benefits, concerning the natural environment [18-21]. Woodland management practices along rivers are able to affect both the timing and volume of stream flows, even assisting in the reduction and smoothening of the flood peaks [22]. Additionally, riparian woodland can reduce the volume of runoff by promoting rainfall infiltration into the soil and eventually decreasing the rate of surface runoff $[23,24]$. Riparian woodland can also aid in the restriction of sediment delivery from the adjacent land, the control of siltation and the increase in the flood storage capacity of the river channels. Furthermore, the tree rooting function can stabilize and strengthen the riverbanks and reduce bank erosion and sedimentation [23,24].

Previous studies showed that more sustainable plans should be adopted, which would provide the maximum possible social and economic resilience against flood events, by protecting and working with the environment in a way that would be fair and affordable both in the short and the long term [25-27]. The utilization of GIS and spatial data in this area plays a leading role. By applying simple spatial techniques in the datasets and combining together multiple criteria and constraints, a wide range of results and maps could be created, showing the significant potential for woodland planting to deal with flooding and diffuse pollution. The main concept of the applied methodology was the Boolean approach, creating true/false statements to present the suitable and unsuitable areas for woodland establishment based on different criteria [28]. The Boolean approach is one of the most common multi-criteria evaluation methods used in land management practices [28]. It is used in spatial mapping to provide binary expressions in order to present which areas belong or not to a designated set.

The aim of the current study is to examine and identify the possible areas, considered as proposed to be included in the planting woodland plan so as to reduce the flood phenomena generation along the Spey River in Scotland, which suffers intensively by such events. In an attempt to achieve this purpose, suitability maps were created presenting the possible sites for woodland planting. The proposed areas were prioritized according to the scope of planting, identifying the catchments in which floodplain and riparian woodland planting was most significant, based on the selected criteria, in order to reduce the flooding downstream. The simplicity and efficiency of the methodology can offer both rapid and 
accurate results at low cost, and could assist researchers and policy makers in the better assessment of flood risk mitigation plans and in improving the efficiency of woodland planting in similar watersheds.

\section{Materials and Methods}

The River Spey is located in the northeastern part of Scotland and it is considered to be the fastest flowing river in Scotland. It is the seventh largest river in Britain, with a watershed area of $3000 \mathrm{Km}^{2}$ and a hydrographic network length of about $36,500 \mathrm{~km}$, of which the Spey mainstream comprises $157 \mathrm{~km}$ [29]. The largest tributary is the Avon, with a catchment size of $543 \mathrm{Km}^{2}$. The other main tributaries are the Dulnain, Feshie, Tromie, Truim, Fiddich, Nethy, Calder and Druie.

The headwaters of the River Spey are located at the high ground of the Monadhliath and Cairngorm Mountain ranges, and flow northeast through narrow and scenic river valleys before discharging into the Moray Firth. There are a few settlements within the catchment that periodically are at risk of major flooding or are affected by localized flooding. Flood incidents that occur in the River Spey are complex and vary by their cause. Not only rainfall events, but other factors such as snowmelt, flash flood events in tributaries, wind effects, the type of ground cover and in-channel deposits may contribute to flooding as well [29]. This area was chosen based on the Scottish Environment Protection Agency (SEPA) flood maps that highlight it as a location vulnerable to flooding (Figure 1).

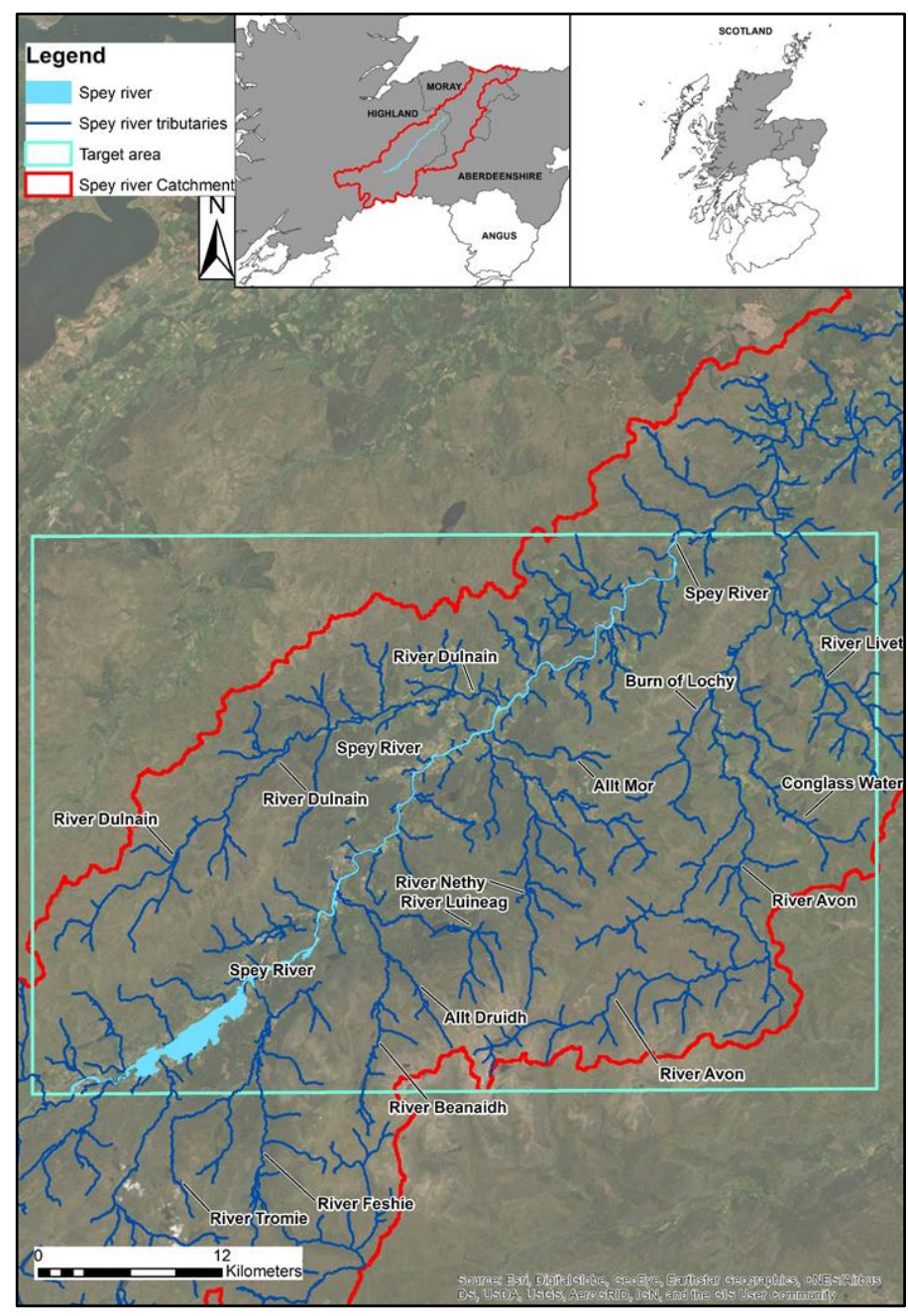

Figure 1. Study area. 
The study area presents a long history of flooding, with the earliest documented flood in 1755 and the most recent major flood in 1990. Floods in the upper catchment of the river mostly occur in the winter, while in the lower main stream and its tributaries, flooding events occur in the summer [30]. Taking into account the major flood events of the late 1980s and early 1990s, combined with the fact that agricultural land is known to flood periodically in the Rothes area, priority was given in the specific area for flood risk assessment and planning.

Forests and woodlands cover only $13 \%$ of the land area all over the United Kingdom (UK). The potential of forests practices offers opportunities for woodland to reduce the impact of pollution from agriculture and urban activities, and assists in flood risk management. In Scotland, the Scottish Forestry Strategy and its implementation plan have provided the basic steps for taking forestry forward through the first half of this century and beyond [2].

The methodology required the identification of suitable and unsuitable areas within the region using a Boolean logic. This multi-criteria evaluation (MCE) is one of the most common methods used in land use management planning, and all the criteria are converted to Boolean (i.e., logical true " 1 "/false " 0 ") statements of suitability for the decision that has to be made. In that way, the areas that are not suitable for consideration can be delineated [28,31]. These expressions could be thought of as constraints and could be merged by some combination of intersection (logical AND) or union (logical OR) operators to conclude on a final statement [28]. All the factors needed to determine the possible areas for woodland and riparian woodland establishment were assigned a new value of suitability (1) or unsuitability (0), and were combined together using the analysis tools that ArcGIS 10.2 provides, in order to generate a final raster image with the areas that meet all the suitability criteria.

The main topographic characteristics of the study area were obtained by the online platform of EDINA Digimap Service [32], including spatial data for the contours (elevation in $5 \mathrm{~m}$ accuracy, datasets about the local and wider road network, railway and the hydrographic network). Additionally, data of the physical and technical objects in the area were necessary in order to fulfill the requirement of this research. Vector data for the urban and rural areas and datasets for the buildings outside the urban areas were also used.

The spatial information about the distribution of forests and woodland in the UK was obtained by the Forestry Commission [2]. The "National Forest Inventory of Scotland" dataset for the year 2013 was used. This dataset provides information about the existing woodland in Scotland for the year of 2013 and the type of vegetation in each area. The classification of this dataset involved all the woodland and non-woodland areas throughout Scotland, including the type of vegetation in detail.

The "Native Woodland Survey of Scotland" provided the Plantations on Ancient Woodland areas and described sites where a woodland area is entirely or partially identified in the ancient semi-natural woodland inventory. These sites are recognized for their important value and contribution to Scottish cultural heritage [33], and therefore, such areas were excluded from the woodland planting plan.

Important information, necessary for the completion of the research, was derived from the Scottish National Heritage official website. Various datasets that concern protected areas were obtained, which included sites of special scientific interest (SSSI), special areas of conservation (SAC), world heritage sites, local nature reserves, country parks and wetlands of international importance (RAMSAR) (Table 1). These datasets played a significant role and were used as constraints and as locations unsuitable for woodland planting.

After building all the constraints, the Raster Calculator tool was used to aggregate all the images into a single raster image that highlighted all the suitable areas for woodland planting based on the selected criteria. The suitable areas had to fulfill all the criteria; therefore, the final image was a binary (Boolean) raster image, highlighting the suitable and unsuitable areas for woodland planting. Thirteen (13) constraints were used in total and are presented in Table 1. The suitable areas were examined and the best locations for woodland and riparian woodland planting, along the Spey River, were selected. An accuracy assessment was undertaken to compare the analysis results with a recent satellite image, in order to identify differences and possible errors or miscalculations. 
Table 1. The list of the 13 constraints and the sources used to support the research.

\begin{tabular}{lccc}
\hline \multicolumn{1}{c}{ Constraint } & Suitable Areas (Value “1”) & $\begin{array}{c}\text { Unsuitable Areas } \\
(\text { Value “0 }\end{array}$ & Source \\
\hline Elevation & below $600 \mathrm{~m}$ AOD & above $600 \mathrm{~m}$ AOD & EDINA Digimap \\
\hline Slope & below $7^{\circ}$ & above $7^{\circ}$ & EDINA Digimap \\
\hline Urban areas & $>500 \mathrm{~m}$ distance & $<500 \mathrm{~m}$ distance & EDINA Digimap \\
\hline Road network & $>300 \mathrm{~m}$ distance & $<300 \mathrm{~m}$ distance & EDINA Digimap \\
\hline Railway network & $>20 \mathrm{~m}$ distance & $<20 \mathrm{~m}$ distance & EDINA Digimap \\
\hline Existing woodland & No woodland & Woodland & Forestry Commission \\
\hline Agricultural land & No agricultural & Agricultural & Forestry Commission \\
\hline $\begin{array}{l}\text { PAWS (Plantations on Ancient } \\
\text { Woodland) }\end{array}$ & No PAWS & PAWS & Scottish National Heritage \\
\hline $\begin{array}{l}\text { Special Areas of Conservation } \\
\text { (SAC) and Sites of Special }\end{array}$ & No SAC and SSSI areas & SAC and SSSI areas & Scottish National Heritage \\
\hline $\begin{array}{l}\text { Wetlandific Interest (SSSI) } \\
\text { importance (RAMSAR sites) }\end{array}$ & No RAMSAR areas & RAMSAR areas & Scottish National Heritage \\
\hline Rivers and open water & No river areas & River areas & EDINA Digimap \\
\hline $\begin{array}{l}\text { Scattered buildings (Outside } \\
\text { of urban areas) }\end{array}$ & No Buildings & Buildings & EDINA Digimap \\
\hline
\end{tabular}

There is a certain elevation that is considered sufficient for woodland establishment in a certain area based on several parameters. The natural tree line for the study area was calculated at $600 \mathrm{~m}$, based on the physical parameters and the topography of the area [34]. The final raster image highlighted the suitable areas that were below $600 \mathrm{~m}$ above the ordinance datum (AOD) with a "1" value and the unsuitable areas that were above $600 \mathrm{~m}$ AOD with a " 0 " value.

This study is focused on floodplains areas with very slight slopes. The slope of the area was used to define the critical eligible angle at which rill erosion begins and the upper limit of land considered suitable for farming. This limit was determined as $7^{\circ}$ [35]. In addition, it is widely known that below the $7^{\circ}$ of terrain slope, the water velocity decreases and as result, the water depth increases, increasing the flood risk in floodplains as well [9]. Furthermore, the low water velocity in floodplains influences the sedimentation process, since sand, gravels and pebbles start to be deposited in various places within the floodplains, altering the water flow paths [36]. All the areas below this limit were considered suitable areas for woodland planting, as areas with flat-moderate steepness being able to support vegetation and reduce rill erosion.

A buffer zone was created around the urban areas. Woodland planting would be excluded from all those areas within the buffer zone. A buffer area of $500 \mathrm{~m}$ around the urban areas was considered a safe distance, taking into account previous research on similar subjects $[23,24]$. The new raster file contained the unsuitable areas within the buffer area and the suitable ones outside of it. Additionally, a dataset containing the buildings across the study area that must be conserved was added by using the same procedure.

The road and forest road network shapefiles were merged to have a complete view of the whole network in one single shapefile. Woodland planting could not be established on the road network, while the effects of forest roads on hydrological processes are highly significant depending on various factors, such as rainfall intensity, morphology, relief, soil depth, geology, cutslope depth, etc. [37]. For security reasons, a buffer area around the roads was created both to protect the road network and to ensure that the woodland management will be more efficient in the future. The road datasets were polyline features; therefore, buffering was applied to each road type, to create the specific road width. 
The primary roads were created by buffering the A roads by $50 \mathrm{~m}$, the secondary roads (B roads) by $20 \mathrm{~m}$ and the minor roads by $5 \mathrm{~m}$. The three buffered datasets were merged together to create a complete road network of the study area. A buffered "safe zone" was determined at $300 \mathrm{~m}$ around the road network $[23,24]$. Likewise, a buffer area of $20 \mathrm{~m}$ was created to construct a polygon that represented the actual size of the railway in the landscape. In this case, an additional buffer area of the railway was not necessary, as the rail tracks are raised above the floodplain on embankments [23,24].

All the areas with existing woodland were excluded. The National Forest Inventory for Scotland dataset was used to identify the existing woodland sites. The final raster image highlighted the suitable areas for woodland planting with a " 1 " value and the unsuitable areas (the existing woodland) with a " 0 " value. The Native Woodland Survey of Scotland dataset provided information about all native woodlands, nearly native woodlands and Plantations on Ancient Woodland (PAW) sites in Scotland. The PAW sites were used as a constraint to exclude them as areas for further woodland planting.

Three additional constraints were created, excluding specially managed natural areas, for potential woodland planting. These important areas are under protection for their natural value and therefore cannot be disturbed by any action, including Special Areas of Conservation (SAC), sites of Special Scientific Interest (SSSI), wetlands of international importance (RAMSAR sites), country parks, world heritage sites and local nature reserves nationwide for Scotland. The areas with agricultural activities and the bare land were also considered as not suitable for woodland planting, and excluded.

Rivers and open water in the study area were excluded from areas of potential woodland planting, using a dataset of the whole hydrographic network of the study area, including information for the open water areas and the tributaries in the wider area. The raster image was classified in two classes, with the " 0 " value representing the rivers and the open water in the area as unsuitable areas for woodland establishment, and the " 1 " value representing the rest of the locations that can be considered suitable for woodland planting based on this factor.

The validation of the proposed suitable areas for woodland planting was conducted using CORINE Land Cover [38]. The polygons of the suitable areas were intersected in the ArcMap with the CLC polygons to investigate the classes of CLC that coincided with the proposed suitable areas. This work was done to ensure that the unsuitable land uses (existing woodland, crops, urban areas, water bodies, etc.) were excluded from the final suitable areas for woodland planting, using the CLC, which was a different source of land use data for the study area.

Concerning the accuracy assessment, satellite images were used to verify the results of the spatial analysis. The detailed information about the satellite images is the following: (1) Sensor-Operational Land Imager (OLI), (2) Date of images 08 Jan 2015, (3) Path-205, (4) Row-20, (5) Cloud Cover-8\%, (6) Sun elevation-9.54018, (7) Sun azimuth-165.3628, (8) Receiving Station-LGN and (9) Scene Start Time—08 Jan 2015 11:15:18 GMT. The satellite images were projected in the British National Grid projection coordinate system to be compatible with the other spatial analysis datasets. The resolution of the satellite image was high enough to perform a comparison between the spatial analysis results and the satellite image, conducting photo interpretation of the satellite images. The polygons of the suitable areas showing the potential woodland planting sites were overlaid above the satellite image. Subsequently, the polygon boundary lines were examined in detail in comparison to the satellite images, in order to verify if there are any significant inconsistencies between the boundary lines and the existing land use conditions of the study area. The following flowchart (Figure 2) shows the steps of the proposed methodology. 


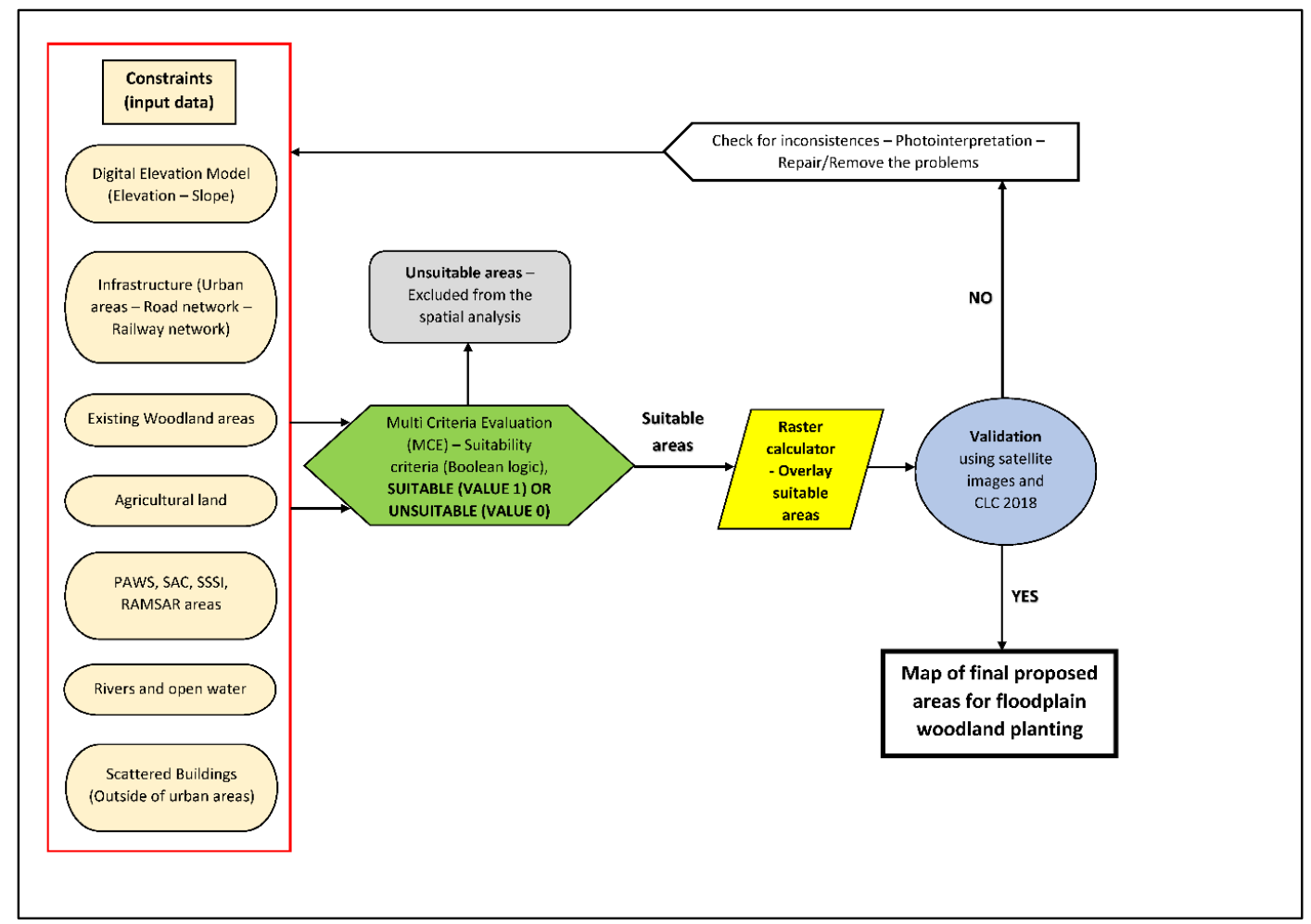

Figure 2. Flowchart of the methodology, data, models, and software that were used.

\section{Results and Discussion}

\subsection{Validation and Accuracy Assessment}

The validation process revealed the significant accuracy of the proposed methodology, since most of the polygons that were created by the intersection of the CLC polygons and the polygons of the suitable areas for woodland planting could be considered suitable for woodland planting. According to the results of the intersection, the areas that are unsuitable for woodland planting (existing woodland, crops, urban areas, water bodies, etc.) are very limited within the proposed areas for woodland establishment (Table 2). Approximately $96 \%$ of the proposed area was covered by moors and heathland, peat bogs, pastures and grasslands, which are areas that could be considered suitable for woodland and riparian woodland establishment under certain circumstances.

The comparison between the polygons of the proposed areas for woodland planting and the satellite images revealed that the accuracy of the proposed methodology was acceptable. In Figure 3, two typical cases of suitable areas for riparian woodland planting in the Spey River are presented. As is evident in Figure 3, the spatial analysis was accurate and the polygons were found to fit on the satellite image, demonstrating a high precision. Additionally, the proposed polygons are located in a flood-prone area, along with the meandering part of the Spey river, where grazing is the main land use, a fact that proves the accuracy of the methodology. 
Table 2. Intersected areas between CLC polygons and the polygons of the suitable areas for floodplain woodland planting.

\begin{tabular}{lcc}
\hline \multicolumn{1}{c}{ CORINE Land Cover Classes } & Intersected Areas $\left.\mathbf{( k m}^{\mathbf{2}}\right)$ & Intersected Areas $\mathbf{( \% )}$ \\
\hline Broad-leaved forest & 0.58 & 0.19 \\
\hline Coniferous forest & 3.43 & 1.15 \\
\hline Discontinuous urban fabric & 0.00 & 0.00 \\
\hline Industrial or commercial units & 0.00 & 0.00 \\
\hline Inland marshes & 0.06 & 0.02 \\
\hline $\begin{array}{l}\text { Land principally occupied by } \\
\text { agriculture, with significant areas } \\
\text { of natural vegetation }\end{array}$ & 0.27 & 0.09 \\
\hline Mixed forest & 0.42 & 0.14 \\
\hline Moors and heathland & 132.06 & 44.09 \\
\hline Natural grasslands & 11.33 & 3.78 \\
\hline Non-irrigated arable land & 0.82 & 0.27 \\
\hline Pastures & 19.55 & 6.53 \\
\hline Peat bogs & 127.02 & 42.40 \\
\hline Sparsely vegetated areas & 2.87 & 0.96 \\
\hline Sport and leisure facilities & 0.43 & 0.14 \\
\hline Transitional woodland-shrub & 0.66 & 0.22 \\
\hline Water bodies & 0.03 & $\mathbf{1 0 0 . 0 0}$ \\
\hline Sum & $\mathbf{2 9 9 . 5 4}$ &
\end{tabular}

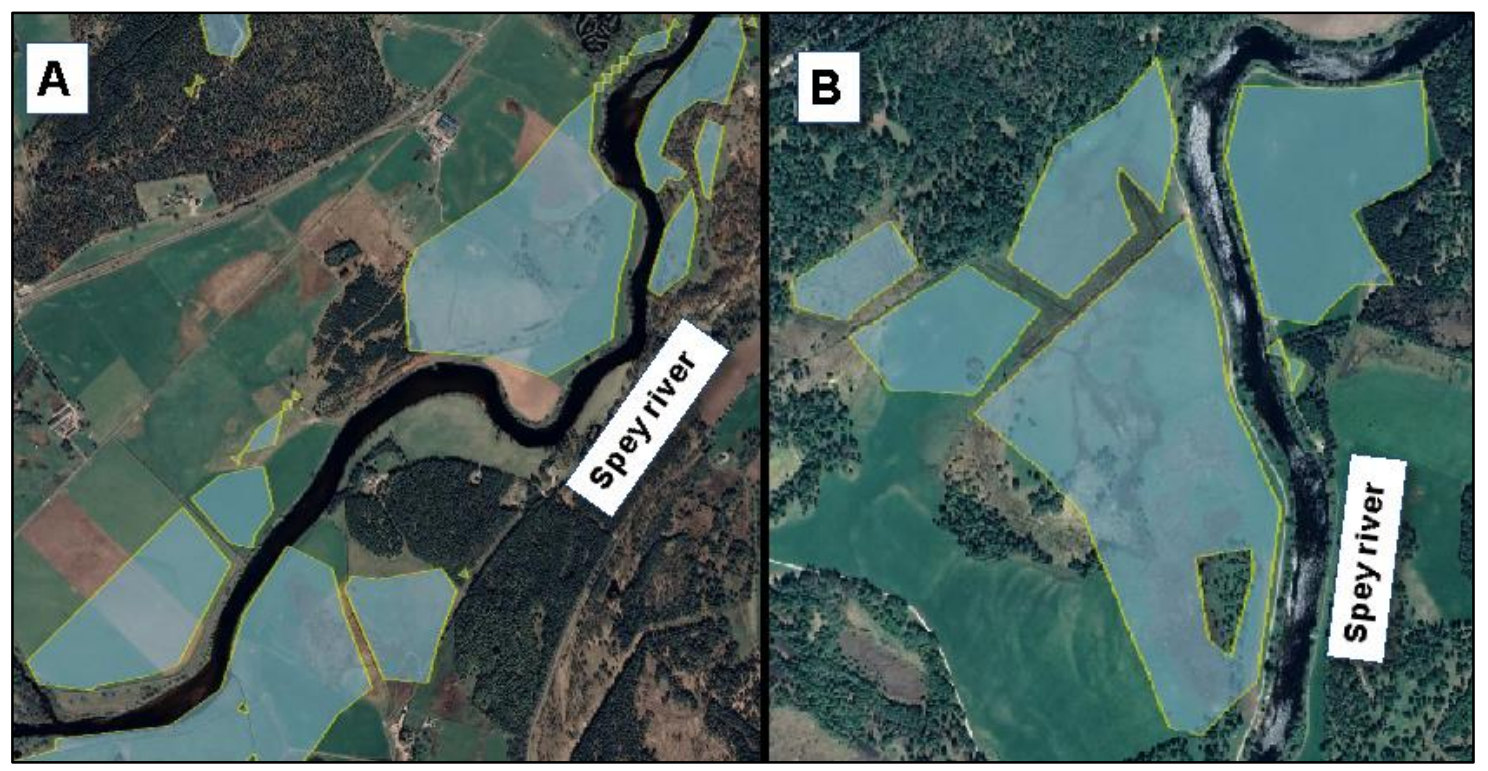

Figure 3. Accuracy of the proposed areas (blue polygons) for floodplain woodland establishment (A,B). 


\subsection{Spatial Analysis Results}

Referring to the woodland management, Figure 4 shows the distribution of the suggested locations divided in four sections. According to the results, the extent of the study area was $2008.85 \mathrm{~km}^{2}$ and the total suggested area for woodland management was $299.54 \mathrm{~km}^{2}$, indicating that $14.92 \%$ of the wider area was suitable for woodland planting. The study area was separated in four parts, the northwestern, the northeastern, the southwestern and the southeastern ones, to examine which part demonstrates the highest potential for woodland establishment (Figure 4).

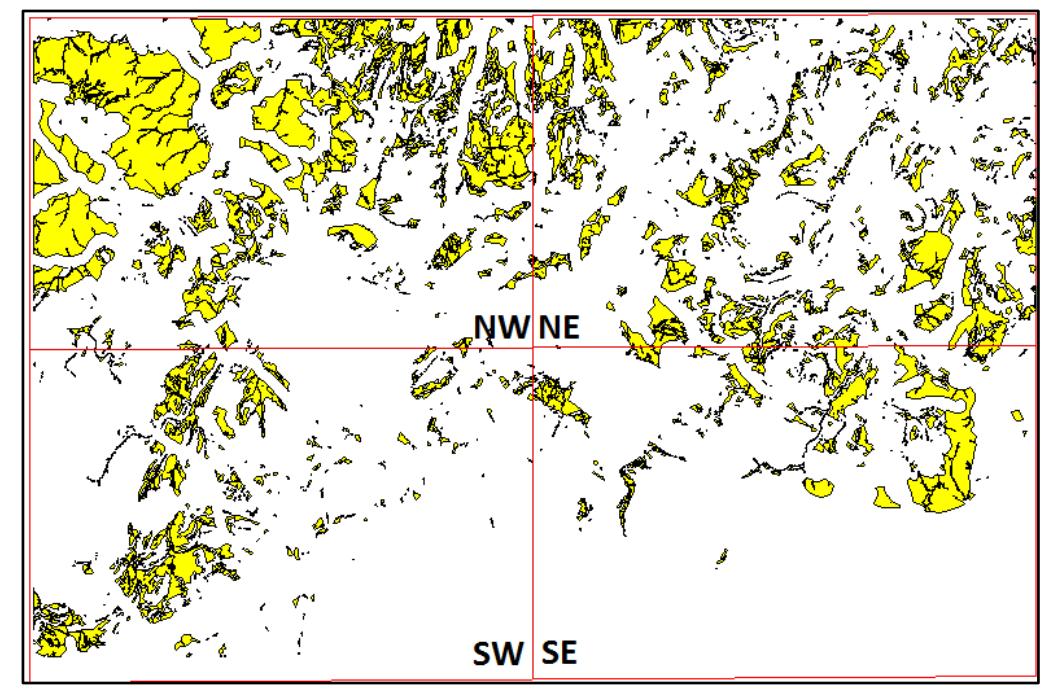

Figure 4. Distribution of woodland planting sites in the study area.

The majority of the suggested locations are concentrated in the northern part of the study area, which is mainly attributed to the fact that the elevation and mean slope in the southern part of the area were higher than the respective qualities of the northern part. The northern part of the study area was more suitable for woodland and riparian woodland planting.

\subsection{Woodland and Riparian Woodland Establishment across Spey River to Reduce Flooding}

In Figure 5, all the tributaries of the Spey River across the target area, along with the suggested woodland management sites that resulted from the spatial analysis, are presented. It was observed that the southern parts of River Avon and the locations around River Tromie and River Feshie were not suitable for riparian woodland establishment based on the selected criteria. On the other hand, the north parts of Avon River, River Fiddich and River Dulnain, and the southwestern and northeastern parts of Spey River itself, could support significant amounts of floodplain woodland.

Almost $20 \mathrm{Km}^{2}$ of land suitable for floodplain woodland were identified in the southwestern part of the Spey River, or $6.67 \%$ of the total suitable areas for woodland establishment. Additionally, $23 \mathrm{Km}^{2}$ of suitable location were identified in the northwestern part of the Spey River, or $7.67 \%$ of the total suitable land. This suggests that $14.5 \%$ of the total suitable land for woodland planting was located along the Spey River. In River Fiddich, $21.5 \mathrm{Km}^{2}$ are suitable for floodplain woodland planting (7.2\% of the total suitable areas). The Avon River is the largest tributary of the Spey River, covering a wide area in the southeastern part. Approximately $53 \mathrm{Km}^{2}$ of suitable area in the Avon River are available for floodplain woodland planting ( $16.6 \%$ of the total suitable areas). Finally, a significant area of approximately $60 \mathrm{Km}^{2}$ ( $20 \%$ of the total suitable area), the biggest concentration compared to the other tributaries, suitable for floodplain woodland planting was identified in Dulnain River. 


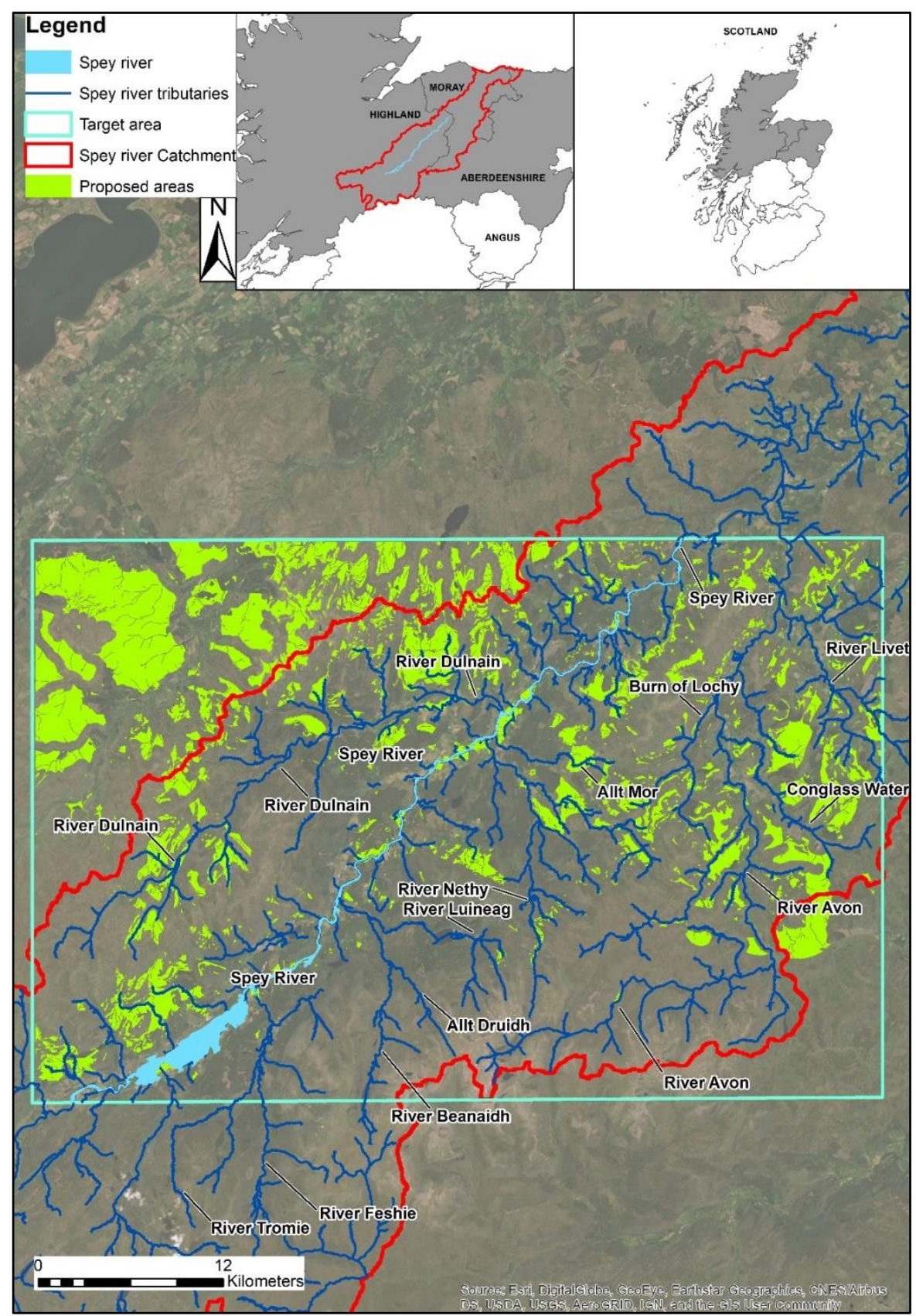

Figure 5. The tributaries of the Spey River and the distribution of the suggested woodland planting sites.

As it was mentioned above, only the areas that fulfill all the 13 criteria would be considered suitable for woodland planting. However, there are areas that satisfy 10,11 or 12 criteria, and it is possible that some of the unsuitable (0) criteria of these areas could be converted into suitable ones, under certain circumstances and after economotechnical study, in the case that there is an imperative need for woodland planting. For example, some areas that are characterized as significant for grazing in the future could be changed and considered suitable for woodland planting. For that reason, a value range map was created (Figure 6) in order to depict the areas that fulfil more suitability criteria. 


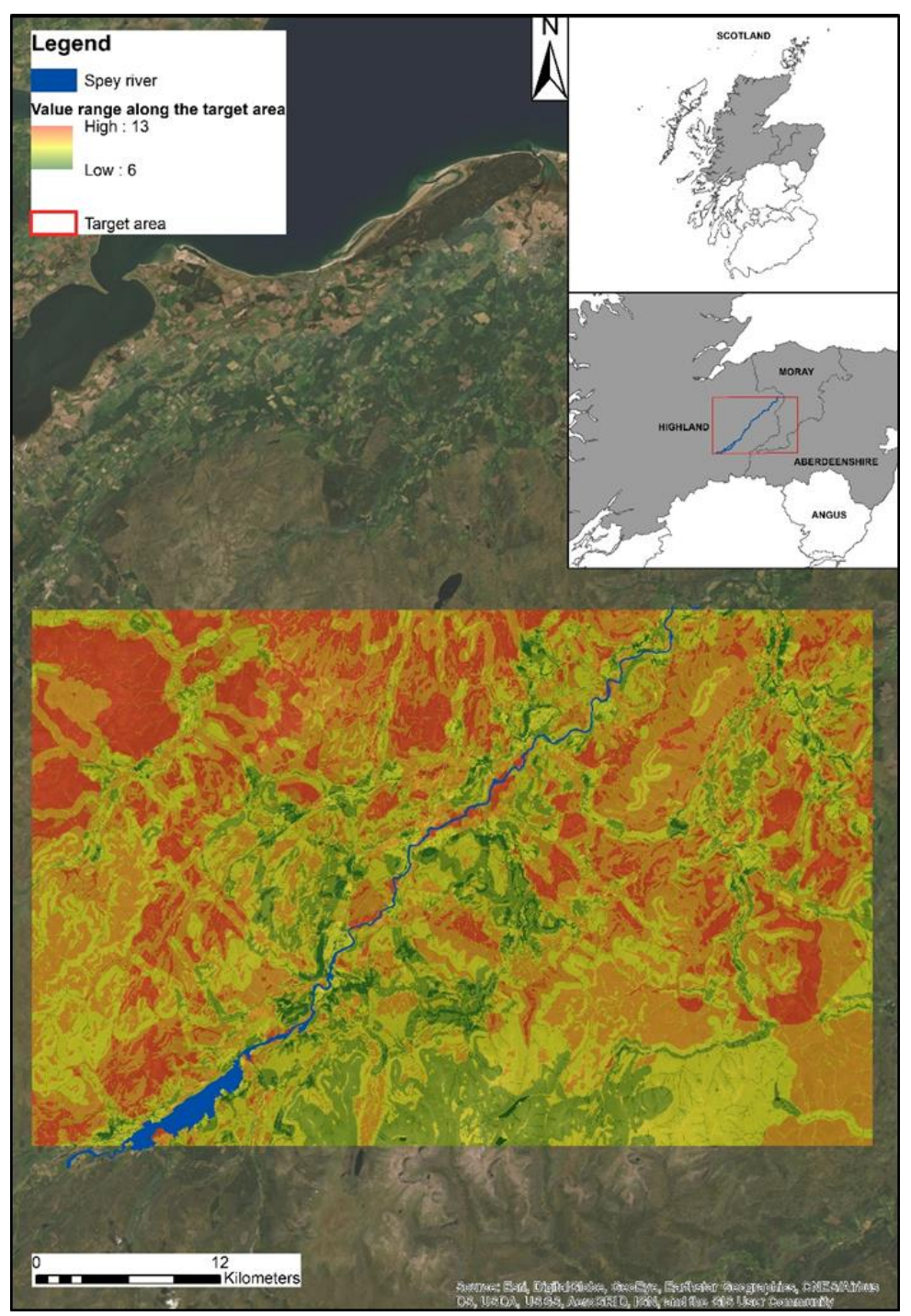

Figure 6. The value range map depicting the areas that fulfil more suitability criteria.

From an economic point of view, grazing is a significant part of the economy in the study area, and significantly contributed, along with the other economic activities (farming, forestry, green tourism business etc.), to the formation of a complicated mosaic of land uses, especially in the floodplain areas, which are combined by more valuable fertile soils. Approximately $50 \%$ of the study area (mainly mountains and moorland) is used for grazing, and the competition between the economic activities (farming, forestry, grazing, sport) in the remaining area is very intense.

In particular, the floodplain areas are fertile arable lands, so any woodland plantations could be exceptionally costly, due to the high value of this land. The financial costs of establishing riparian and floodplain woodland and the losses of farming and grazing land are the main constraints that restrict any further action for woodland plantation. Economotechnical study is necessary in similar areas, where the competition for high-value land between the financial interests of different economic groups is rife. The results showed that more sustainable plans should be adopted, which would provide the maximum possible social and economic resilience against flooding events, by protecting and working with the environment in a way that it would be fair and affordable in the both short and long term [27].

There is an imperative need for additional research work on the hydrology management of the Spey River, taking into consideration also the results of global warming, to deal with the flash floods. Research showed that in the Spey catchment, floods associated with a 100-year flood return period were increased by $50 \%$, using historical information in order to predict future flood frequency [30]. 
Towers and Thompson [39] showed that significant opportunities for woodland planting in the wider area were available during the late 1980 's, in a study based on different criteria but showing favorable circumstances for woodland planting. Ormerod et al. [25] studied the influence of the riparian woodland on the habitat structure in Britain, and concluded that this kind of management can be used positively to influence the stream communities. Van der Horst and Gimona [26] studied the areas for new farm woodlands to support biodiversity in northeastern Scotland using a GIS-based multi-criteria methodology. They concluded that the highest potential biodiversity benefits are located at the edges of major agricultural areas, the riparian zones and nearby areas to mature native pine woods. Previous research provides good examples on this subject in other cases in the United Kingdom over the past 10 years, working with the Forestry Commission Research Agency. The opportunity mapping for woodland to reduce flooding in the York and Humber region [23], in the river Derwent in Cumbria [23] and finally in the River Tay catchment [40] show possibilities for floodplain woodland restoration areas.

However, floodplain woodland plantations in some cases can also decrease the surface water generation and groundwater recharge, in cases wherein water resources are already under pressure [41], highlighting the need for the careful determination of the forest plantation sites and the land management direction. The influence of floodplain woodlands on floods is not fully comprehended. Despite the multiple benefits of woodland planting, it is not possible to predict the exact consequences of flood mitigation in the area, or the reduction in the peak flows. There is an uncertainty concerning the effect of floodplain woodland on altering the water velocity. The presence of woodland in the floodplain increases the surface roughness values, resulting in a reduction in water flow velocity, and consequently, the water level within and upstream the forested area is increased $[9,18]$.

The research results reveal that woodland planting could be feasible and, in some cases, necessary, taking into account both the environmental and hydrological benefits that could be provided in the study area and in similar watersheds. However, additional research should be conducted, in order to determine the current reach capacity of similar rivers, so as to predict the flood locations in the future. In each case, prior to any action, the social, economic and environmental factors should be considered, while sustainable flood management and proposals for flood control, including a strategic vision for flood management planning at the catchment or sub-catchment scale, should be promoted.

\section{Conclusions}

This study presented the opportunities of woodland and floodplain woodland establishment in a certain area around the Spey River in Scotland, aiming to mitigate the flood events. The simplicity of the methodology can offer both rapid and accurate results, while the datasets can be easily accessed and are available in a convenient type/format. The results revealed significant opportunities for both woodland and floodplain woodland planting in the study area, and the methodology could be applied in numerous other catchments of similar conditions. The results showed that a $177.5 \mathrm{Km}^{2}(59.2 \%)$ area of the total suitable areas was identified as a potential area for floodplain woodland establishment along the Spey River and its tributaries. River Dulnain was the tributary that demonstrated the highest potential for floodplain woodland planting, followed by River Avon, River Fiddich and the southwestern and northeastern parts of the Spey River. The locations around River Tromie and River Feshie did not show any potential for woodland or floodplain woodland establishment. Riparian woodland can play a crucial role in assisting the future river management plans, and can contribute to a more sustainable planning. Additional research should be conducted to combine these results in order to determine more specific outcomes. For instance, research should be done into the types of vegetation that could be established in each area (species composition) to fulfill different purposes. Various datasets with spatial information about the requirements of the different species can be combined. Additionally, hydrological factors should also be combined, such as spatial information for the water properties, the chemical composition of the water to show properties of the water quality, and possible interactions between the natural environment, the wildlife and the local industry. In this way, possible 
pollution hot spots could be identified, where woodland establishment could play a significant role in enhancing environmental quality.

The recent development of the Geographical Information Systems combined with the modern methods used to address the described issues and the increasing capabilities of the latest software can provide more detailed and accurate results to answer more complex questions. Additional tools could be used to verify the results, such as GPS systems and high-quality remote sensing data in order to analyze, simulate and predict possible outcomes in the future, such as flood-risk areas.

The hydrological and environmental factors combined with the social and economic benefits that woodland management provide show that woodland practices can play a leading role in the future land use management plans, because of their multiple character and their positive effect on the ecosystems' quality and the local societies.

Author Contributions: Conceptualization: Christos Tzioutzios and Aristeidis Kastridis; methodology: Christos Tzioutzios and Aristeidis Kastridis; software: Christos Tzioutzios; validation: Aristeidis Kastridis; formal analysis: Aristeidis Kastridis; investigation: Christos Tzioutzios; resources: Christos Tzioutzios; data curation: Christos Tzioutzios and Aristeidis Kastridis; writing-original draft preparation: Christos Tzioutzios; writing-review and editing: Aristeidis Kastridis. All authors have read and agreed to the published version of the manuscript.

Funding: This research received no external funding.

Acknowledgments: The authors would like to thank EDINA Digimap Service, Scottish National Heritage and UK Forestry Commission for the provided datasets used in this study.

Conflicts of Interest: The authors declare no conflict of interest.

\section{References}

1. Khosravi, K.; Melesse, A.M.; Shahabi, H.; Shirzadi, A.; Chapi, K.; Hong, H. Flood susceptibility mapping at Ningdu catchment, China using bivariate and data mining techniques. In Extreme Hydrology and Climate Variability; Melesse, A.M., Abtew, W., Senay, G., Eds.; Elsevier: Amsterdam, The Netherlands, 2019; pp. 419-434.

2. Forestry Commission. Forests and Water, UK Forestry Standard Guidelines; Forestry Commission: Edinburgh, UK, 2011.

3. Jie, Y.; Dapeng, Y.; Zhane, Y.; Kung, W.; Shiyun, X. Modeling the anthropogenic impacts on fluvial flood risks in a coastal mega-city: A scenario- based case study in Shanghai China. Landsc. Urban. Plan. 2015, 136, 144-155. [CrossRef]

4. Kastridis, A.; Kamperidou, V. Evaluation of the post-fire erosion and flood control works in the area of Cassandra (Chalkidiki, North Greece). J. For. Res. 2015, 26, 209-217. [CrossRef]

5. Marafuz, I.; Rodrigues, C.; Gomes, A. Analysis and assessment of urban flash floods on areas with limited available altimetry data (Arouca, NW Portugal): A methodological approach. Environ. Earth Sci. 2015, 73, 2937-2949. [CrossRef]

6. Diakakis, M.; Andreadakis, E.; Nikolopoulos, E.I.; Spyrou, N.I.; Gogou, M.E.; Deligiannakis, G.; Katsetsiadou, N.K.; Antoniadis, Z.; Melaki, M.; Georgakopoulos, A.; et al. An integrated approach of ground and aerial observations in flash flood disaster investigations. The case of the 2017 Mandra flash flood in Greece. Int. J. Disaster Risk Reduct. 2019, 33, 290-309. [CrossRef]

7. Faccini, F.; Luino, F.; Paliaga, G.; Sacchini, A.; Turconi, L.; de Jong, C. Role of rainfall intensity and urban sprawl in the 2014 flash flood in Genoa City, Bisagno catchment (Liguria, Italy). Appl. Geogr. 2018, 98, 224-241. [CrossRef]

8. Kastridis, A.; Stathis, D. Evaluation of Hydrological and Hydraulic Models Applied in Typical Mediterranean Ungauged Watersheds Using Post-Flash-Flood Measurements. Hydrology 2020, 7, 12. [CrossRef]

9. Kastridis, A.; Kirkenidis, C.; Sapountzis, M. An integrated approach of flash flood analysis in ungauged Mediterranean watersheds using post-flood surveys and unmanned aerial vehicles. Hydrol. Process. 2020. [CrossRef]

10. Suriya, S.; Mudgal, B.V. Impact of urbanization on flooding; The Thirusoolam sub-watershed- A case study. J. Hydrol. 2012, 210-219. [CrossRef] 
11. Segura-Beltrán, F.; Sanchis-Ibor, C.; Morales-Hernández, M.; González-Sanchis, M.; Bussi, G.; Ortiz, E. Using post-flood surveys and geomorphologic mapping to evaluate hydrological and hydraulic models: The flash flood of the Girona River (Spain) in 2007. J. Hydrol. 2016, 541, 310-329. [CrossRef]

12. Kastridis, A.; Stathis, D. The Effect of Rainfall Intensity on the Flood Generation of Mountainous Watersheds (Chalkidiki Prefecture, North Greece). In Perspectives on Atmospheric Sciences; Karacostas, T., Bais, A., Nastos, P., Eds.; Springer International Publishing: Cham, Switzerland, 2017; pp. 341-347. [CrossRef]

13. Jodar-Abellan, A.; Valdes-Abellan, J.; Pla, C.; Gomariz-Castillo, F. Impact of land use changes on flash flood prediction using a sub-daily SWAT model in five Mediterranean ungauged watersheds (SE Spain). Sci. Total Environ. 2019, 657, 1578-1591. [CrossRef]

14. Hall, J.; Arheimer, B.; Borga, M.; Brázdil, R.; Claps, P.; Kiss, A.; Kjeldsen, T.R.; Kriauciuniene, J.; Kundzewicz, Z.W.; Lang, M.; et al. Understanding flood regime changes in Europe: A state-of-the art assessment. Hydrol. Earth Syst. Sci. 2014, 18, 2735-2772. [CrossRef]

15. Kundzewicz, Z.W. Non-structural flood protection and sustainability, International Water Resources Association. Water Int. 2009, 27, 3-13. [CrossRef]

16. Rouillard, J.J.; Ball, T.; Heal, K.V.; Reeves, A.D. Policy implementation of catchment scale flood risk management: Learning from Scotland and England. Environ. Sci. Policy 2015, 50, 155-165. [CrossRef]

17. Pielech, R.; Anioł-Kwiatkowska, J.; Szczęśniak, E. Landscape-scale factors driving plant species composition in mountain streams and spring riparian forests. Ecol. Manag. 2015, 347, 217-227. [CrossRef]

18. Huw, T.; Nisbet, T.R. An assessment of the impact of floodplain woodland on flood flows. Water Environ. J. 2007, 21, 114-126. [CrossRef]

19. Riis, T.; Kelly-Quinn, M.; Aguiar, F.; Manolaki, M.; Bruno, D.; Bejarano, M.; Clerici, N.; Rosário Fernandes, M.; Franco, J.; Pettit, N.; et al. Global Overview of Ecosystem Services Provided by Riparian Vegetation. BioScience 2020, 70, 501-514. [CrossRef]

20. González, E.; Felipe-Lucia, M.R.; Bourgeois, B.; Boz, B.; Nilsson, C.; Palmer, G.; Sher, A.A. Integrative conservation of riparian zones. Biol. Conserv. 2017, 211, 20-29. [CrossRef]

21. Wierzcholska, S.; Dyderski, M.K.; Pielech, R.; Gazda, A.; Smoczyk, M.; Malicki, M.; Horodecki, P.; Kamczyc, J.; Skorupski, M.; Hachułka, M.; et al. Natural forest remnants as refugia for bryophyte diversity in a transformed mountain river valley landscape. Sci. Total Environ. 2018, 640, 954-964. [CrossRef]

22. Nisbet, T.R.; Broadmeadow, S. Opportunity Mapping for Trees and Floods, Final Report to Parrett Catchment Project Wet Woodland Group; Forest Research: Surrey, UK, 2003; p. 3.

23. Broadmeadow, S.; Nisbet, T. Opportunity Mapping for Woodland to Reduce Flooding in the Yorkshire and the Humber Region; Forest Research: Surrey, UK, 2010; p. 64.

24. Broadmeadow, S.; Nisbet, T. Opportunity Mapping for Woodland to Reduce Flooding in the River; Centre for Forestry and Climate Change, Forest Research: Cumbria, UK, 2010.

25. Ormerod, J.S.; Rundle, D.S.; Lloyd Clare, E.; Douglas, A. The Influence of Riparian Management on the Habitat Structure and Macroinvertebrate Communities of Upland Streams Draining Plantation Forests. J. Appl. Ecol. 1993, 30, 13-24. [CrossRef]

26. Van der Horst, D.; Gimona, A. Where new farm woodlands support biodiversity action plans: A spatial multi-criteria analysis. Biol. Conserv. 2005, 123, 421-432. [CrossRef]

27. Werritty, A. Sustainable flood management: Oxymoron or new paradigm? Area 2006, 38, 16-23. [CrossRef]

28. Eastman, R. Multi-criteria evaluation in GIS. In Geographical Information Systems; Longley, P.A., Goodchild, M.F., Maguire, D.J., Rhind, D.W., Eds.; Whiley: New York, NY, USA, 1999; Chapter 35; pp. 493-502.

29. Spey Catchment Steering Group. River Spey Catchment Management Plan 2003. Available online: https: //www.speyfisheryboard.com/wp-content/uploads/2014/12/Spey-Catchment-managementPlan2003.pdf (accessed on 1 January 2015).

30. Black, R.A.; Fadipe, D. Use of historic water level records for re- assessing flood frequency: Case study of the Spey catchment. Water Environ. J. 2009, 23, 23-31. [CrossRef]

31. Cheng, C.H.; Thompson, R.G. Application of boolean logic and GIS for determining suitable locations for Temporary Disaster Waste Management Sites. Int. J. Disaster Risk Reduct. 2016, 20, 78-92. [CrossRef]

32. EDINA Digimap Service. Available online: http://edina.ac.uk/digimap (accessed on 1 February 2015).

33. Thompson, R.; Humphrey, J.; Harmer, R.; Ferris, R. Restoration of Native Woodland on Ancient Woodland Sites, Forestry Commission Practice Guide; Forestry Commission: Edinburgh, UK, 2003. 
34. Conroy, J.W.H.; Johnston, R.C. The Cairngorms in Relation to the UK Environmental Change Network (ECN). Bot. J. Scotl. 1996, 48, 137-154. [CrossRef]

35. McHugh, M.; Wood, G.; Walling, D.; Morgan, R.; Zhang, Y.; Anthony, S.; Hutchins, M. Prediction of Sediment Delivery to Watercourses from Land: Phase II. RED Technical Report No P2-209; Environment Agency: Bristol, $\mathrm{UK}, 2002$.

36. Hjulstrom, F. Studies of the morphological activity of rivers as illustrated by the River Fyris, Bulletin. Geol. Inst. Upsalsa 1935, 25, 221-527.

37. Kastridis, A. Impact of Forest Roads on Hydrological Processes. Forests 2020, 11, 1201. [CrossRef]

38. Corine Land Cover (CLC); European Environment Agency (EEA). 2018. Available online: https://land. copernicus.eu/pan-european/corine-land-cover/clc2018 (accessed on 22 June 2020).

39. Towers, W.; Thompson, S. The Spey catchment-an example of the application of the land capability for forestry classification. Scot. Geogr. Mag. 1988, 104, 116-122. [CrossRef]

40. Broadmeadow, S.; Huw, T.; Shah, N.; Nisbet, T. Opportunity Mapping for Woodland Creation to Improve Water Quality and Reduce Flood Risk in the River Tay Catchment-A Pilot for Scotland; The Research Agency of the Forestry Commission, Forest Research: Edinburgh, UK, June 2013.

41. Van Dijk, A.; Keenan, R. Planted forests and water in perspective. Ecol. Manag. 2007, 251, 1-9. [CrossRef]

Publisher's Note: MDPI stays neutral with regard to jurisdictional claims in published maps and institutional affiliations.

(C) 2020 by the authors. Licensee MDPI, Basel, Switzerland. This article is an open access article distributed under the terms and conditions of the Creative Commons Attribution (CC BY) license (http://creativecommons.org/licenses/by/4.0/). 